\title{
HEMATOLOGICAL AND BLOOD CHEMISTRY VALUES IN A SEMI-FREE POPULATION OF WHITE-NOSED COATIS (NASUA NARICA) IN LA VENTA TABASCO, MEXICO
}

\author{
MARÍA DE JESÚS ROVIROSA-HERNÁNDEZ, ${ }^{1 *}$ FRANCISCO GARCÍA- \\ ORDUÑA, ${ }^{1}$ JORGE E. MORALES-MÁVIL, ${ }^{1}$ LAURA TERESA HERNÁNDEZ-

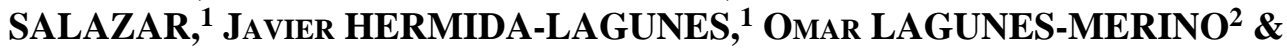 \\ TLAOLI FUENTES-ANAYA ${ }^{2}$ \\ ${ }^{1}$ Laboratorio de Biología de la Conducta, Instituto de Neuroetología, Universidad Veracruzana, \\ Xalapa, Veracruz, México. \\ ${ }^{2}$ Posgrado en Neuroetología, Universidad Veracruzana, Xalapa, Veracruz, México. \\ Dr. Luis Castelazo s/n, Km 3.5 Carretera Xalapa-Veracruz, Col. Industrial Las Animas, C.P. 91190, \\ Xalapa, Veracruz, Apartado Postal 566. \\ *Autor corresponsal: <jrovirosa@uv.mx>
}

Rovirosa-Hernández, M. J., F. García-Orduña, J. E. Morales-Mávil, L. T. Hernández-Salazar, J. Hermida-Lagunes, O. Lagunes-Merino \& T. Fuentes-Anaya. 2012. Hematological and Blood Chemistry values in a semi-free population of white-nosed coatis (Nasua narica) in La Venta Tabasco, Mexico. Acta Zoológica Mexicana (n. s.), 28(2): 391-400.

ABSTRACT. Clinical analyses of Procyonidae groups are extremely limited. The aim of this work was to obtain gender baseline data on the blood chemistry and hematological values of Nasua narica, in conditions of semi-freedom. For this, 14 males adults and 30 females adults were sedated with ketamine hydrochloride and captured. The blood was collected from the femoral artery, and conventional techniques were used to analyze the samples. Males showed statistical differences in hemoglobin, hematocrit and erythrocytes, compared to females. The females on the other hand having higher platelet counts than the males. For blood chemistry, the females showed higher concentrations of magnesium compared with the males. On the other hand, the males showed higher values in Albumin/Globulin relation with respect to the females. These results could be useful as reference values for adult individuals of Nasua narica, in order to develop future criteria regarding the health-disease processes of this species.

Key words: Nasua narica, biometry, serum biochemistry, reference values, male, female.

Rovirosa-Hernández, M. J., F. García-Orduña, J. E. Morales-Mávil, L. T. Hernández-Salazar, J. Hermida-Lagunes, O. Lagunes-Merino \& T. Fuentes-Anaya. 2012. Valores hemáticos y química sanguínea de una población en semi-libertad de coati nariz blanca (Nasua narica) en La Venta Tabasco, México. Acta Zoológica Mexicana (n. s.), 28(2): 391-400.

RESUMEN. Los análisis clínicos a grupos de Procyonidos son muy limitados. El objetivo principal del presente trabajo fue obtener valores basales de química sanguínea y biometría hemática de Nasua

Recibido: 25/10/2011; aceptado: 09/03/2012. 
narica, en condiciones de semi-libertad. Para esto, 14 machos y 30 hembras adultos fueron sedados con hidrocloruro de ketamina y capturados. La sangre se colectó de la arteria femoral; fueron utilizadas técnicas convencionales para analizar las muestras. Los machos mostraron diferencias estadísticas en hemoglobina, hematocrito y eritrocitos comparado con las hembras. Las hembras, por su parte tuvieron mayor número de plaquetas que los machos. Para química sanguínea, las hembras mostraron mayores concentraciones de magnesio en comparación con los machos. Por otro lado los machos mostraron valores más elevados en la relación Albumina/Globulina, con respecto a las hembras. Estos resultados podrían ser útiles como valores de referencia para los individuos adultos de Nasua narica, a fin de desarrollar futuros criterios en relación con los procesos de salud-enfermedad de esta especie.

Palabras clave: Nasua narica, biometría, química sanguínea, valores de referencia, machos, hembras.

\section{INTRODUCTION}

Understand and investigate the diseases of free-living individuals are vital aspects in management wildlife programs. Also the need to conserve several wild animal species in semi-free-range has attracted attention to the potential transmission of infectious microorganisms, their impact on the health of individuals and groups of the wild animals and their effect on conservation programs (Russel 1992). Animals kept in captivity or bred in semi-free-range areas, such as zoological gardens or parks may become infected with pathogens in their enclosures (Taema et al., 2008). It is therefore fundamental to know the health conditions of captive animals in order to guarantee their wellbeing (Wirz et al., 2008). A method for determining animal health is blood sampling and analysis. Haematological and serum biochemical values can obtain easily and are useful in determining the health or general condition of wild fauna (Riviello \& Wirz 2001; Flabian et al., 2008). In fact, the constituents of blood as well as many of the chemicals it carries provide fundamental information for medical diagnosis of disease (Morrison 1999; Moore 2000; Wirz et al., 2008).

For some animal species, standard values of hematological variables are well defined. However concerning the Procyonidae, published date have often been based on few species, on small numbers of individuals, or derived from a single sample per animal, or reported values combined for all age groups or both sex or infected with a parasite.

The white-nosed coati (Nasua narica) is a Carnivore with great plasticity of behavior, which is an important factor in the success of the species within its wide geographical distribution, which extends from northeastern Colombia to southern Arizona and New Mexico (Gompper 1995). In Mexico, in particular, it is mainly distributed in the tropical forests of both oceanic slopes (Valenzuela 1998).

Its diet consists mainly of fruits and terrestrial invertebrates (Kaufmann 1962; Russell 1982; Saénz 1994; Gompper 1996; Valenzuela 1998). When fruits are scarce, however, it is reported that bands focus more on leaf -litter fauna and the males forage for larger prey, among which are some small vertebrates (Smythe 1970; Rusell 1981; 1982; 1983). Moreover, in captivity the coati's diet is modified and may include al- 
most any kind of food. Currently, the coati is cataloged in a position of least concern (LC) according to IUCN (Samudio et al., 2008).

The objective of present study is to establish reference values for biometric and blood chemistry in male and female adults of Nasua narica in semi-free conditions. These parameters will be critical in implementing conservation and management programs for this species, because will be used as reference to compare such values with other populations in the wild and in captivity. This is very important as will help us to detect and also, develop strategies in order to solve health problems with the aim to contribute to the conservation and survival of this species.

\section{MATERIALS AND METHODS}

Geographical location. The individuals in this study are located in Museum Park "La Venta", a protected natural area of the state government of Tabasco, where ecotourism is being developed. Located in downtown Villahermosa, Tabasco, México $\left(18^{\circ} 20^{\prime} \mathrm{N}, 93^{\circ} 18^{\prime}\right)$ at a height of only10 $\mathrm{m}$ above sea level, the park covers an area of 8.0 ha, of which 6.0 ha have heterogeneous vegetation, both native and introduced. Its climate is warm-humid, with an average annual rainfall of $1600-2000 \mathrm{~mm}$ and a temperature of $22-26^{\circ} \mathrm{C}$ (Fuentes et al., 2003).

The vegetation consists of elements of high and medium evergreen forest, with secondary vegetation introduced (Capello \& Alderete 1986). The lower middle stratum has trees 12 to $15 \mathrm{~m}$ in height. In the lower strata there are abundant herbaceous plants and thorny shrubs 2 to $8 \mathrm{~m}$ high. Some species present are: Sapindus saponaria (soap), Byrsonima crassifolia (nance), Mangifera indica (mango), Gliricidia sepium (cocoite) Haematoxylum campechianum (red stick), Chrisophyllum caimito (star apple), Coccoloba barbadensis (uvero) Partmentiera edulis (cuajilote), Pouteria sapota (mamey zapote), Acrocomia mexicana (cocoyol), Tabernaemontana alba (milky) and Tamarindus indica (tamarind) (Capello \& Alderete 1986). Mangifera indica and Pouteria sapota were recorded in the diet of the coatis in this area (Fuentes-Anaya in preparation). In addition, daily eggs, bread, oatmeal and bananas are provided for them.

\section{Experimental Design}

Anesthesia and Capture. This study was approved by the institutional guidelines of the Universidad Veracruzana, the Federal Government of Mexico's Secretariat of Environment and Natural Resources (SEMARNAT; official permits \# 09/GS2132/05/10), and the Management Unit for Conservation of Wildlife (UMA) 2000, Museum Park "La Venta” INE/CITIES/DGVS/ZOO-E-002-97-TAB.

During the period from November 30 to December 2, 2009, 44 adult individuals were captured within the park: 30 females and 14 males. Each individual was 
sedated by using a 3-ml syringe and darts made with 3x32mm needles, which were fired through a blowgun, approximately two to five meters from the trigger. Each dart contained a dose of $10-15 \mathrm{mg} / \mathrm{kg}$ (0.5 ml - Modified from Kreeger \& Ameno 2007) of ketamine hydrochloride (Inoketam ${ }^{\circledR} 1000$ Virbac, S.A. Lab. Guadalajara, Jal. Mexico). When the dart had hit its mark, the individuals were weighed in a hanging scale (LightLine ${ }^{\circledR}$ Spring Scales, Forestry Suppliers, Inc. Jackson MS, USA).

After the last blood sampling, each was placed temporarily in an individual cage until complete recovery from the anesthesia. Thereafter, they were returned to the site of capture and observed until they rejoined their social group.

Blood Sampling. A syringe (BD-Vacutainer ${ }^{\circledR} 21 \mathrm{Gx} 32 \mathrm{~mm}$, México, DF) was used to extract $2.5 \mathrm{ml}$ of blood from the femoral artery. Each blood sample was then split into various fractions as follows:

Hematic biometry. For hematic biometry, $0.5 \mathrm{ml}$ was placed in tubes (Microtainer ${ }^{\circledR}$ Brand Becton Dickinson, Franklin Lakes, New Jersey, USA), in which ethylendiaminotetracetic acid (EDTA) was included as an anticoagulant. This was mixed gently and maintained at ambient temperature in continuous agitation for 30 minutes. Then it was stored at $4^{\circ} \mathrm{C}$ for less than 8 hours, for subsequent laboratory analysis.

We estimated the concentration of eleven different constituents: Hemoglobin Concentration, Hematocrit, Red Blood Cells, Mean Corpuscular Volume, Mean Corpuscular Hemoglobin, Mean Corpuscular Hemoglobin Concentration and Platelets, White Blood Cells, Monocytes, Lymphocytes, and Granulocytes. These were quantified with Beckman Coulter equipment ACT-5-DIF (Beckman Coulter de Mexico S.A. de C.V.) by means of the cyanmethemoglobin spectrophotometry methodology, mathematical ratio and electrical impedance.

Serum biochemistry. For the blood biochemistry test, $2 \mathrm{ml}$ of blood were emptied into a tube (BD-Vacutainer ${ }^{\circledR} \mathrm{SST}^{\mathrm{TM}}$ ) with a gel to separate it from the serum. This was centrifuged at $1,096 \mathrm{~g}$ for $10 \mathrm{~min}$. (COLE -PARMER ${ }^{\circledR}$; Equipar S.A. de C.V. México), and then the serum was collected and placed in clean vials. These were transported at $4^{\circ} \mathrm{C}$ and stored at $-20^{\circ} \mathrm{C}$ for less than 8 hours, for subsequent analysis. For blood chemistry, we determined the concentration of eighteen different parameters: Glucose, Blood Urea Nitrogen, Urea, Uric Acid, Total Protein, Albumin, Globulin, Albumin/Globulin Ratio, Creatinine, Cholesterol, Triglycerides, Alkaline Phosphatase, Calcium, Phosphorus, Magnesium, Chloride, Potassium and Sodium, which were quantified with a Johnson \& Johnson Vitros 250 Chemistry Analyzer (Johnson \& Johnson de México, S.A. de C.V.) by means of the reflectance spectrophotometry methodology and direct potentiometry.

The hemolyzed, icteric or lipemic samples were discarded to avoid analytical interferences.

Statistical analyses. Thereafter, a descriptive statistic (Me $\pm \mathrm{SD}$ ) was applied in order to obtain the mean weights of the specimens, to determine gender differences in 
the weights applied a one-way ANOVA. The Kolmogorov-Smirnoff test was applied to these data to establish whether the distribution was normal. Finally a Mann-Whitney test was applied to determine the differences among the values in each parameter of chemistry and hematic biometry between males and females, with $\mathrm{p}<0.05$ being considered as significant. Moreover was performed a Pearson correlation between the weight of individuals and hematology and blood chemistry values was made. The analyses were carried out in the statistic package SIGMA STAT 3.5 (SYSTAT ${ }^{\circledR}$, Charter Oak, CA. USA).

\section{RESULTS}

The average weight of the males was significantly higher $(F=61.944, \mathrm{p}<0.0001)$ than that of the females $(5.6 \pm 0.23$ vs. $4.0 \pm 0.06 \mathrm{~kg})$. There was no significant correlation between weight and hematological values; however, there was negative correlation between weight of females $(r=-0.43)$ and males $(r=-0.71)$ with alkaline phosphatase and a positive correlation between the weight of the males and the values of potassium and creatinine ( $r=0.76$ and $r=0.65$ respectively).

Hematic biometry. This shows the mean, standard deviation and range values of each hematological parameter for males and females. As the values failed the normality test (Kolmogorov-Smirnov), was applied the Mann-Whitney test, the males showed significant differences compared to those found in the females, within the parameters of hemoglobin $(U=80 ; p=0.001)$, hematocrit $(U=108.5 ; p=0.011)$, and red blood cell count $(\mathrm{U}=119 ; \mathrm{p}=0.021)$. However, the females showed a difference in platelets $(U=129 ; p=0.023)$ compared with the males, all other parameters showing no significant differences between the genders (Table 1).

Serum Biochemistry. The males showed significant differences in albumin/globulin relation $(U=38 ; p=0.001)$ and creatinine $(U=53.5 ; p=0.027)$ compared to the females; whereas in the parameter of magnesium, the females showed significant differences $(U=53.5 ; p=0.009)$, compared to the males. The other parameters showed no significant differences between the genders (Table 2).

\section{DISCUSSION}

The results of blood counts between genders showed that the females were found to have lower values than the males in three parameters (hemoglobin, hematocrit and red blood cells); this may be due to the sexual dimorphism presented, which is consistent with other reports on mammals (Samonds et al., 1974; Abouheif \& Fairbairn 1997; Larsson et al. 1999; Riviello \& Wirz 2001; Suardiaz et al., 2004; Miller et al., 2009; Mikniene et al., 2010).

When comparing these three parameters with those reported for Nasua nasua by (Sampaio et al., 2001), our animals showed higher values in these parameters. How- 
Rovirosa-Hernández et al. Haematic parameters of Nasua narica

Table 1. Hematological values (mean \pm SD), maximum and minimum range of 44 male and female adults white-nose coatis (Nasua narica). Hemoglobin, hematocrit and red blood cell count were significantly higher in males than females. Platelets were significantly higher in female than males. Mann-Whitney test, $p<0.05$.

\begin{tabular}{lccccc}
\hline \multicolumn{1}{c}{ Parameters } & Male $\mathrm{n}=14$ & Máx Mín & Female $\mathrm{n}=30$ & Máx Mín & U-test \\
\hline Hemoglobin (g/dL) & $10.71 \pm .43$ & $13.9-8.7$ & $9.21 \pm .18$ & $12.7-7.6$ & $.001^{*}$ \\
Hematocrit $(\%)$ & $31.84 \pm 1.48$ & $44.3-25.2$ & $27.86 \pm .61$ & $39.1-22.5$ & $.011^{*}$ \\
Red Blood Cell count & $6.54 \pm .27$ & $8.86-5.3$ & $5.81 \pm .13$ & $8.39-4.3$ & $.021^{*}$ \\
$\left(\times 10^{6} / \mathrm{uL}\right)$ & & & & & \\
Mean Corpuscular Volume (fl) & $48.64 \pm .72$ & $54-45$ & $48.03 \pm .36$ & $52-45$ & .540 \\
Mean Corpuscular Hemoglobin & $16.42 \pm .31$ & $19.3-15.2$ & $15.87 \pm .11$ & $17.7-14.8$ & .141 \\
(pg) & & & & & \\
Mean Corpuscular Hemoglobin & $33.79 \pm .34$ & $36.1-31.4$ & $33.13 \pm .17$ & $34.7-31$ & .093 \\
Concentration $(\mathrm{g} / \mathrm{dl})$ & & & & & \\
Platelet $\left(\times 10^{3} / \mathrm{uL}\right)$ & $512.71 \pm 19.55$ & $636-393$ & $595.43 \pm 22.07$ & $904-385$ & $.023^{*}$ \\
White blood cell $\left(\times 10^{3} / \mathrm{uL}\right)$ & $9.48 \pm .84$ & $14.7-5.20$ & $8.61 \pm .43$ & $15.3-5.1$ & .668 \\
Monocyte $\left(\times 10^{3} / \mathrm{uL}\right)$ & $2.42 \pm .27$ & $4.0-1.1$ & $2.13 \pm .10$ & $3.2-1.1$ & .605 \\
Lymphocyte $\left(\times 10^{3} / \mathrm{uL}\right)$ & $3.37 \pm .33$ & $5.8-2.1$ & $2.72 \pm .15$ & $5.8-1.5$ & .089 \\
Garanulocytes $\left(\times 10^{3} / \mathrm{uL}\right)$ & $3.69 \pm .39$ & $6.3-1.7$ & $3.76 \pm .30$ & $10.3-1.8$ & .899 \\
\hline
\end{tabular}

ever with respect to that reported by Pimentel (1994, cited by Silva et al., 1999) for same specie in captivity conditions, Nasua narica shows lower values in red blood cells and hematocrit, and similar ones in hemoglobin, whereas a slight increase is shown over that reported for Nasua nasua infected with Trypanosoma evansi (Silva et al., 1999). Regarding the white blood cell values, we found a lower concentration of these in respect to Nasua nasua in both conditions. These results allow us to suggest that our individuals are not sick (Silva et al., 1999) or stressed as a result of immobilization and handling during the capture (Wallace \& Oppenheim 1996). On the other hand, we must take into account that there may be large variations in the blood levels of wild populations in regard to both intrinsic (inflammatory responses, immunological investment, aerobic capacity) and extrinsic factors (environmental and host factors - Beldomenico et al., 2008).

In regard to platelet count, we found that females showed a greater number of them compared to males. Platelets play an important role in the response to vascular damage and are also involved in the inflammatory response (Roitt et al., 1998), increasing in number when injuries occur (Semple et al., 2002). We suggest that this difference is probably related to the greater social activity presented by females, as observed in the bands that they form (Gommper 1996; Valenzuela, 1998) they also 
Table 2. Blood biochemistry values (mean \pm SD), maximum and minimum range of 44 male and female adults white-nose coatis (Nasua narica). Albumin/Globulin relation, creatinine was significantly higher in males than females. Magnesium was significantly higher in female than males. Mann-Whitney test, $p<0.05$.

\begin{tabular}{lccccc}
\hline \multicolumn{1}{c}{ Parameters } & Male $\mathrm{n}=14$ & Máx Mín & Female $\mathrm{n}=30$ & Máx Mín & U-test \\
\hline Glucose (mg/dL) & $80.09 \pm 8.70$ & $133-39$ & $74.36 \pm 4.28$ & $114-45$ & .789 \\
Blood Urea Nitrogen (mg/dL) & $16.27 \pm 2.09$ & $29-7$ & $17.40 \pm 0.76$ & $29-11$ & .321 \\
Urea (mg/dL) & $34.82 \pm 4.48$ & $62.1-15.0$ & $37.25 \pm 1.64$ & $62.1-23.5$ & .328 \\
Ureic Acid (mg/dL) & $1.15 \pm 0.9$ & $2.0-0.9$ & $1.15 \pm 0.9$ & $1.5-0.9$ & .293 \\
Total Protein (g/dL) & $7.02 \pm .22$ & $8.2-6.2$ & $7.05 \pm .14$ & $8.3-5.7$ & .647 \\
Albúmin (g/dL) & $3.09 \pm .10$ & $3.6-2.8$ & $2.90 \pm .06$ & $3.5-2.4$ & .244 \\
Globulin (g/dL) & $3.93 \pm .13$ & $4.7-3.4$ & $4.15 \pm .09$ & $5.1-3.2$ & .187 \\
Albumin/Globulin relation & $0.78 \pm .01$ & $0.85-0.63$ & $0.69 \pm .01$ & $0.81-0.60$ & $.001 *$ \\
(mg/dL) & & & & & \\
Creatinine (mg/dL) & $1.17 \pm .06$ & $1.5-0.9$ & $0.99 \pm .02$ & $1.2-0.8$ & $.027 *$ \\
Cholesterol (mg/dL) & $173.0 \pm 13.57$ & $259-102$ & $197.09 \pm 6.69$ & $258-143$ & .163 \\
Triglyceride (mg/dL) & $28.90 \pm 3.35$ & $55-20$ & $27.36 \pm 1.08$ & $35-20$ & .688 \\
Alkaline Phosphatase (U/L) & $50.27 \pm 5.52$ & $79-28$ & $46.13 \pm 2.07$ & $75.0-34.0$ & .703 \\
Calcium (mg/dL) & $8.67 \pm .15$ & $9.5-8.0$ & $8.34 \pm .11$ & $9.2-7.3$ & .117 \\
Phosphorous (mg/dL) & $5.17 \pm .23$ & $6.2-3.9$ & $5.13 \pm .12$ & $6.3-4.2$ & .939 \\
Magnesium (mmol/L) & $1.87 \pm .07$ & $2.4-1.6$ & $2.08 \pm .04$ & $2.4-1.7$ & $.009 *$ \\
Chloride (mmol/L) & $114.81 \pm 1.32$ & $122.0-108.0$ & $115.04 \pm 1.06$ & $125-105$ & .746 \\
Potassium (mmol/L) & $4.58 \pm .10$ & $5.2-4.2$ & $4.64 \pm .08$ & $5.5-4.1$ & .745 \\
Sodium (mmol/L) & $142.27 \pm 1.70$ & $152-136$ & $141.90 \pm 1.35$ & $154-129$ & .984 \\
\hline
\end{tabular}

have greater individual interactions during coalitions periods with the young (Hirsch 2007; Fuentes-Anaya, in preparation).

Other authors mention that these differences in females may be due to cyclical secretion of gonadal hormones (Emms \& Lewis 1985). However, our sampling was carried outside this reproductive period (Gommper 1995).

The results of blood chemistry showed significant gender differences, the males having higher concentrations in the albumin/globulin relation and in creatinine as compared to the females, while the latter showed a higher concentration of magnesium ions. A clinical laboratory test for humans reports an albumin/globulin relation in a range of 3.3-5.9 g/ml and plasma magnesium between 1.5 and $2 \mathrm{mmol} / \mathrm{L}$, neither being reported by gender (Morrison 1999). The same range applies to the values for the coatis. As to the statistical difference in the concentration of creatinine, this may 
be related to the body mass of individuals, its concentration being the result of muscle metabolism (Morrison 1999).

In general, all values in hematology and blood chemistry reported in this study, were within the ranges shown in the ISIS database. The differences in minimum and maximum values of blood cells, is likely due to ISIS values include analysis of young individuals, while our results only represent adult organisms. It is reported that young individuals mammals have hematologic differences from adults because the young are growing and developing (Sealander 1963; Franzmann \& Schwartz 1988; Flaiban et al., 2008).

It is important to note that most of the reports on the hematological values in different species of Procyonidae are made using individuals in captivity, either because they are subject to investigation or enclosed in zoos. To our knowledge this is the first report for blood test in Nasua narica under semi-freedom conditions in Southeastern of Mexico, and our findings underline the differences between genders in hematology test and blood chemistry. Therefore, our results could be useful as reference values for adult individuals of Nasua narica, in order to develop future criteria regarding the health-disease processes of this species.

ACKNOwLEDgments. The authors would like to thank all the individuals who helped to collect samples for this project and whose contribution was essential to its success. We thank Dr. Carlos Rafael Blázquez Domínguez, Principal of the Hospital-School of Gynecology, U.V., for his valuable help with bloodsampling analyses, and we express special thanks to Warren Haid, who corrected the manuscript. The authors O.L.M and T.F.A were granted by the Consejo Nacional de Ciencia y Tecnología (CONACYT) Mexico.

\section{REFERENCES CITED}

Abouheif, E. \& D. J. Fairbairn. 1997. Comparative analysis of allometry for sexual size dimorphism: Assessing rensch's rule. The American Naturalist, 149: 540-562.

Beldomenico, P. M., S. Telfer, S. Gebert, L. Lukomski, M. Bennett \& M. Begon. 2008. The dynamics of health in wild field vole populations: a haematological perspective. Journal of Animal Ecology, 22:984-997.

Capello, G. S. \& A. Alderete. 1986. Guía Botánica del Parque Museo de la Venta. Gobierno del Estado de Tabasco. Instituto Nacional de Investigaciones sobre Recursos Bióticos, Villahermosa, Tabasco, México. 73 pp.

Emms, H. \& G. P. Lewis. 1985. Sex and hormonal influences on platelets sensitivity and coagulation in the rat. British Journal of Pharmacology, 86: 57-563.

Evans, R. H. 2002. Raccoons and Relatives (Carnivora, Procyinidae). In: D Heard (Ed). Zoological Restraint and Anesthesia. International Veterinary Information Service. Ithaca, New York.

Flaiban, K. K. M. C., K. A. H. Spohr, L. S. Malanski, W. K. Svoboda, M. M. Shizawa, C. L. S. Hilst, L. M. Aguilar, G. Ludwin, F. C. Passos, I. T. Navarro, M. R. S. Balarin \& J. A. N. Lisbôa. 2008. Hematologic values of free-ranging Cebus cay and Cebus nigritus in Southern Brazil. International Journal of Primatology, 29: 1375-1382 
Franzmann, A. W. \& Schwartz, C. C. 1988. Evaluating condition of Alaskan Back bears with blood profiles. Journal of Wild Management. 52: 63-70.

Gompper, M. E. 1995. Nasua narica. Mammalian Species, 487: 1-10.

Gompper, M. E. 1996. Sociality and asociality in white-nosed coatis (Nasua narica): foraging costs and benefits. Behavioral Ecology, 7: 254-263.

Hirsch, B. T. 2007. Spoiled brats: Is extreme juvenile agonism in ring-tailed coatis (Nasua sasua) dominance or tolerated aggression?. Ethology, 113: 446-456.

International Species Information System. 2002. Nasua narica. In: Colleted Proceedings, American Association of Zoo Veterinarians. USA. http://www.isis.org

Kaufmann, J. H. 1962. Ecology and social behavior of the coati, Nasua narica, on Barro Colorado Island, Panama. University of California Publications in Zoology, 60: 95-222.

Kreeger, T. J. \& Ameno, J. M. 2007. Handbook of wildlife chemical immobilization. Third edition. Sunquest, USA.

Larsson, M. H. M. A., E. H. Birgel, F. J. Benesi, E. H. Birgel, Jr, P. Lazaretti, J. D. L. Fedullo, C. E. Larsson, S. R. Molina, P. P. C. A. Guerra \& C. S. Prada. 1999. Hematological values of Cebus apella anesthetized with ketamine. Brazilian Journal of Veterinary Research and Animal Science, 36: 131-135.

Mikniene, Z., J. A. Sutkevicius, A. Kucinskas, A. Januskevicius, S. Kerziene \& J. Kucinskiene. 2010. Evaluation of blood biochemistry, morphology and the amount of isthmuses in the eosinophils nuclei for standard dark mink (Mustela vision). Veterinarija ir Zootechnika, 49: 61-65.

Miller, D. L., J. Schrecengost, A. Merrill, J. Kilgo, R. H. Scott, K. V. Miller \& C. A. Baldwin. 2009. Hematology, parasitology, and serology of free-ranging coyotes (Canis latrans) from South Carolina. Journal of Wildlife Diseases, 45: 863-869.

Moore, D. M. 2000. Hematology of nonhuman primates, pp. 1133-1144. In: B. F, Feldman, J. G. Zinkl \& N. C. Jain (Eds.). Schalm’s veterinary hematology. 5th Ed. Lippincott Williams \& Wilkins: Philadelphia.

Morrison, T. K. 1999. Evidence relating to the leukocites, pp 97-108. In: G. A, Lemus, (Ed.). Clinical laboratory and diagnostic test. El Manual Moderno, México.

Riviello, C. \& A. Wirz. 2001. Haematology and blood chemistry of Cebus apella in relation to sex and age. Journal Medical of Primatology, 30: 308-312

Roitt, I. M., J. Brostoff \& D. K. Male. 1998. Immunology. $5^{\text {th }}$ ed. Gower Medical Publishing Ltd. London: Mosby.

Russell, R. 1992. Campylobacter jejuni colitis and immunity in primates: epidemiology of natural infection, pp. 148-156. In: I. Nachamkin, M. J. Blaser, \& L. S. Tompkins (Eds.). Campylobacter: current status and future trends. American Society for Microbiology, Washington, D. C.

Russell, J. K. 1983. Altruism in coati bands: nepotism or reciprocity’?, pp. 263-290. In: S. K. Wasser. (Ed.). Social behavior of female vertebrates. Academic Press, New York.

Russell, J. K. 1982. Timing of reproduction by coatis (Nasua narica) in relation to fluctuations in food resources, pp. 413-431. In: E. G. Leigh Jr, A. S. Rand, D. M. Windsor (Eds.). The ecology of a tropical forest: seasonal rhythms and long-term changes. Smithsonian Institute Press, Washington, D. C.

Russell, J. K. 1981. Exclusion of adult male coatis from social groups: protection from predation. Journal of Mammalogy, 62: 206-208.

Saénz, J. M. 1994. Ecologia del pizote (Nasua narica) y su papel como dispersador de semillas en el bosque seco tropical, Costa Rica. (dissertation) Heredia, Costa Rica: Universidad National de Costa Rica 212 pp. 
Samonds, K.W., L. M. Ausman \& D. M. Hegsted. 1974. Hematological development of the Cebus monkey (Cebus albifrons and apella). Folia Primatology, 22: 72-79.

Sampaio, L. A., Veloso, N. A. L. \& da Silva, G. M. 2001. Order Carnivora, Family Procyonidae (Raccoons, Kinkajous), pp 317-322. In: M. E. Fowler \& Z.S. Cubas (Eds.) Biology, medicine and surgery of South American wild animals. Iowa State University Press.

Samudio, R., R. Kays, A. D. Cuarón, J. L. Pino \& K. Helgen. 2008. Nasua narica. In: Red List of Threatened Species IUCN 2010. IUCN. Version 2010.4.

Sealander, J. A. 1964. The influence of body size, season, sex, age and other factors upon some blood parameters in small mammals. Journal of Mammalogy (45)4: 598-616.

Semple, S., G. Cowlishaw \& P. M. Bennett. 2002. Immune system evolution among anthropoid primates: parasites, injuries and predators. Proceeding of the Royal Society B: Biological Sciences 269: 1031-1037.

Silva, R. A. M. S., A. M. Victórico, L. Ramirez, A. M. R. Dávila, V. Trejano \& A. M. Jansen. 1999. Hematological and Blood chemistry alterations in coatis (Nasua nasua) naturally infect by Trypanosoma in the Pantanal, Brazil. Pathologie Parasitaire communication. Revue d Elevage et de Medecine Veterinaire des Pays Tropicaux, 52: 119-122.

Smythe, N. 1970. The adaptive value of the social organization of the coati (Nasua narica). Journal of Mammalogy, 51: 818-820.

Suardiaz, J., C. Cruz \& A. Colina. 2004. Eritropoyesis, pp. 205-210. In: Laboratorio Clínico Ciencias Medicas (Eds.). La Habana, Cuba.

Taema, M.M., Bull, J.C., Macgregor, S.K., Flach, E.J., Boardman, W.S. \& Routh A.D. 2008. Retrospective study of Campylobacter infection in a zoological collection. Applied and Environmental Microbiology, 74: 1332-1338.

Valenzuela, D. 1998. Natural history of the white-nosed coati, Nasua narica in the tropical dry forests of western México. Revista Mexicana de Mastozoología. 3: 26-44.

Wallace, C. \& Y. C. Oppenheim. 1996. Hematology and serum chemistry profiles of captive Hoffmann's two-toed sloths (Cholocpus didactyhus). Journal of Wildlife Diseases, 34: 555-566.

Wirz, A., Truppa, V., Riviello, M. C. 2008. Hematological and plasma biochemical values for captive tufted capuchin monkeys (Cebus apella). American Journal of Primatology, 70: 463-472. 